\title{
SAFETY ANALYSIS OF DRINKING WATER ON THE TEST - ORGANISMS
}

M. VERGOLYAS, Candidate of Biological Sciences, Associate Professor of the Department International Academy of Ecology and Medicine

E-mail:vergolyas@meta.ua

https: //doi.org/10.31548/bio2019.03.004

Providing the population with quality drinking water is an important task in maintaining human health. In world practice, when assessing water quality, in addition to chemical analysis, a total toxicological assessment of water is carried out, based on the use of various biotesting methods. Assessment of the quality of drinking water using bioassay methods in recent decades has gained particular relevance in connection with the rapid increase in the number of potentially dangerous chemical compounds that pollute natural sources of drinking water supply. The aim of the study was to assess the toxicity of drinking water from various sources of water supply (tap, artesian, packaged) using hematological parameters of test organisms: Danio rerio fish, Xenopus spur frogs and Wistar rats. It was revealed that the chemical composition of tap and bottled water did not meet the requirements of SanPiN 2.2.4-171-10 (State Sanitary and Hygienic Norm). Water from the water supply had an excess of Fe content ( 6.3 times), and bottled water. "Heavenly Krinitsa" exceeded Si and Mn (1.5 and 1.2 times, respectively). In the analysis of peripheral blood in experimental animals, these waters showed a cytotoxic effect - an increase in the number of monocytes, neutrophils and eosinophils and a decrease in lymphocytes. The detected changes in the cellular composition of the peripheral blood of experimental animals may indicate the activation of nonspecific natural resistance, the development of inflammatory and allergic reactions. Indicators of peripheral blood in test organisms that consumed water from the pump room were close to control.

Keywords: drinking water, biotesting, test organisms, cytotoxicity, white blood cell count

Introduction. The problem of drinking water quality is becoming increasingly acute in most countries of the world, including Ukraine. One of the important components of Ukraine's environmental safety is the quality of drinking water; providing the population with quality drinking water is one of the most important tasks of maintaining human health.

The population's consumption of packaged drinking water is rapidly increasing every year. The deterioration in the quality of bottled drinking water is associated with a change in their chemical composition and microbiological contamination, as well as violations of the duration and storage conditions, features of water treatment technologies, falsification of products (mismatch of the quality of bottled water with the data on the label).

When assessing water quality in world practice, in addition to the usual chemical analysis of the most common pollutants, a total toxicological assessment of water is carried out, based on the use of various biotesting methods. Biotesting is a methodological technique based on an assessment of the action of an environmental factor, including toxic, on a living organism, its individual function or system of organisms. 
Assessment of the quality of drinking water using bioassay methods in recent decades has gained particular relevance in connection with the rapid increase in the number of potentially dangerous chemical compounds that pollute natural sources of drinking water supply.

Living organisms are able to respond to lower concentrations of toxicants that are not recorded by technical means. At the same time, biotesting provides an integrated assessment of the degree of toxicity of polluted waters for living organisms, taking into account the synergism and antagonism of the interaction of different solutes.

Analysis of recent research and publications. The use of ecotoxicological biotests (plant and animal test organisms) and their cellular biomarkers is extremely important for objective and comprehensive monitoring of the increasing number of xenobiotics that pollute the aquatic environment, most of which are not standardized by existing standards, but have the ability to cause a variety of toxic, cytotoxic, genotoxic or mutagenic effects. The universality of cell organization opens up wide possibilities for toxicological studies using various groups of animals and plants and subsequent extrapolation of the results to cells and the human body (Trachtenberg I.M., Kovalenko V.M., Kokshareva N.V., Zhminko P.G., Chumak V.T. \& Baula O.P., 2008; Goncharuk V.V., Vergolyas M.R. \& Boltina I.V., 2013).

According to the literature (Titsa N.U., 2003), the effect of toxicants on the blood system is characterized by both general and specific manifestations. The main mechanisms of the hematotoxic effect are the violation of erythropoiesis, inhibition of the synthesis of heme and globin, as well as the membrane and cytotoxic effect, which leads to a decrease in the lifespan of cells and their morphofunctional changes.

In particular, the effect of water on the hematological parameters of living organ- isms, which are an indicator not only of the physiological state of the body, but also one of the main criteria for identifying pollution of drinking water (Goncharuk V.V., Vergolyas M.R. \& Boltina I.V., 2013; Vergolyas M.R., 2019).

The blood system is very sensitive to the action of potentially dangerous exogenous factors. Blood cells are among the first to encounter substances and compounds that enter the body. This necessitates a mandatory assessment of the state of peripheral blood, provided that their toxic properties are determined (Vergolyas M.R., 2016).

To assess the cytotoxicity of water samples, their effect on the test organism (fish) was studied. When determining the cytotoxicity of the aqueous medium, the formed elements of fish blood (leukocytes) were used as a biomarker, their number was determined, and the cytotoxicity of the aqueous medium was evaluated by their ratio in the control and experimental samples (Goncharuk V.V. \& Vergolyas M.R., 2013).

The aim of the study. Comparative assessment of the toxicity of drinking water from different water supply sources using hematological indicators of representatives of different systematic groups and trophic levels - aquatic organism (Danio rerio fish), amphibian organism (Xenopus spur frogs) and warm-blooded animals (Wistar rats).

Fish is a highly organized hydrobiont and, directly due to its habitat in water, the life cycle and chemical reactions in its body proceed faster than in other vertebrates (frogs, rats, rabbits, birds) (Vergolyas M.R. \& Goncharuk V.V., 2016). Pisces are recommended to use substances for screening potentially harmful to humans, causing deformities and cancers, as well as genotoxic substances, falling into drinking water. This is confirmed by the correlation coefficients between mutagenicity indices on blood cells in fish and lymphocytes of human peripheral blood. The obtained val- 
ues of the linear correlation coefficients indicate the relationship of almost all indicators determined in fish and the number of damaged aberrant metaphases with metabolic activation on lymphocytes (Goncharuk V.V., Vergolyas M.R. \& Boltina I.V., 2013).

Xenopus spur frogs, this type of test organism is widespread in developmental biology. The ease of manipulation with amphibians and their embryos made them an important object in embryology, developmental biology and aquatic toxicology. They are also popular among aquarium animals, like fish, relatively undemanding to the conditions of keeping pets.

Wistar rats are one of the main types of experimental animals used in biological and medical research to determine the mechanisms of various diseases, the effectiveness and toxicity of drugs and chemicals.

Materials and research methods. In the work analyzed tap water from the tap; artesian water delivered from the pump room, which is located in the park to them. Shevchenko; and bottled water "Heavenly Krinitsya" packaged in 18.9 liters without gas, purchased from a distribution network in Kiev.

Control water was prepared under laboratory conditions in accordance with the recommendations of DSTU 4174: 2003 (State standard of Ukraine). In water samples, the chemical composition (the content of micro and macro elements) was determined by the method of atomic emission spectroscopy with inductively coupled plasma. The content of micro and macro elements in control water did not exceed the standard MPC (Maximum Permissible Concentration) according to SanPiN 2.2.4-171-10 (State Sanitary and Hygienic Standards).

Biotesting was carried out on 40 adult Danio rerio fish weighing 2-4 grams and Xenopus spur frogs weighing 50-80 grams, cultured in laboratory conditions at the International Academy of Ecology and Medicine.
Test organisms were divided into 4 groups of 10 individuals. Each group was placed in aquariums with control, tap, artesian and packaged water. After exposure after 96 hours, blood samples were taken from each vein from each individual. Blood was taken from fish from the tail vein from fish, from frogs from the hind leg vein. The analysis of peripheral blood was carried out by a standard method (Goncharuk V.V. \& Vergolyas M.R., 2013).

At the same time, an experiment was conducted on 40 sexually mature white rats of the male Wistar strain weighing 160-180 grams. Rats were also divided into 4 groups (10 animals each). All animals were in stationary vivarium conditions on a standard food and special water regime for 6 weeks. In particular, rats of group No. 1 drank control water; group number 2 - water from the water supply. Rats of group No. 3 drank water from the pump room, and animals of group No. 4 drank packaged water of the brand "Heavenly Krinitsya". To determine hematological parameters, blood was taken from the tail vein after exposure for 6 weeks.

A general blood test with leukocyte counting was performed according to the standard method (Balakhovsky I.S., 1982).

Statistical processing of the results was carried out using methods of variation statistics using statistical analysis programs Microsoft Excel. Arithmetic mean, mean deviation, arithmetic mean error were calculated. The difference between the indicators was determined by t-student test (Antomonov M.Yu., 2006).

Research results and discussion. According to a chemical analysis, the content of individual elements in tap water was higher than in control water. In particular, the content of As (1.6 times), Ba (700 times), Ca (2.8 times), Mn (4000 times), $\mathrm{Pb}$ (4 times), $\mathrm{Sr}$ (14.6 times), Si (98 times), Zn (300 times), significantly exceeded the MPC value (maximum permissible concentration) for drinking water, the Fe content (6.3 times). 
The composition of water No. 2 from the pump room was close to the control water. According to the results of measurements in «Heavenly Krinitsya» water, in comparison with the control one, it was also found that the content of individual macro- and microelements was exceeded, namely, $\mathrm{Na}$ (2.5 times), $\mathrm{P}$ (35.7 times), Sr (4 times), Si (788 times), Zn (47.8 times). The content exceeded the MPC value (maximum permissible concentration).

Thus, the obtained results allow us to conclude that the content of macro- and microelements control and artesian water fully meets the requirements for drinking water SanPiN 2.2.4-171-10 (State Sanitary and Hygienic Norm). Water from the water supply system has an excess of Fe content (6.3 times), and bottled water "Heavenly Krinitsa" has an increase in $\mathrm{Si}$ and $\mathrm{Mn}$ (1.5 and 1.2 times, respectively).
Biotesting and cytological analysis of the studied water samples were carried out. The quantitative characteristics of the peripheral blood leukocyte formula of test organisms were detected using microscopy. The cytotoxic assessment of various types of drinking water (tap, artesian, packaged) on blood cells is shown in the table below:

From the data obtained, it is seen that in fish that were in tap water, an increase in the number of monocytes, neutrophils and eosinophils (from 2.4\% to 12.6\%) and a decrease in lymphocytes (up to $68.4 \%$ ) were found. In packaged water, there was also an increase in monocytes, neutrophils and eosinophils (from $4.4 \%$ to $14.9 \%$ ), a decrease in lymphocytes (up to 64.8\%) compared with control water. In the sample of water from the pump room, significant differences compared to control water were not observed (Table 1).

\section{Evaluation of the cytotoxicity of the studied drinking water on the peripheral blood cells of fish Danio rerio, Xenopus spur frogs and Wistar rats}

\begin{tabular}{|c|c|c|c|c|c|c|}
\hline & \multicolumn{5}{|c|}{ Blood elements, \% } \\
\hline & & $\begin{array}{l}\text { Lympho- } \\
\text { cytes }\end{array}$ & Monocytes & $\begin{array}{l}\text { Neutrophils } \\
\text { segmented }\end{array}$ & $\begin{array}{c}\text { Neutrophils } \\
\text { band }\end{array}$ & Eosinophils \\
\hline \multirow{3}{*}{$\begin{array}{l}\text { 1.Water con- } \\
\text { trol }\end{array}$} & fish & $86,7 \pm 2,62$ & $5,7 \pm 0,93$ & $5,2 \pm 1,24$ & $1,6 \pm 0,63$ & $0,8 \pm 0,46$ \\
\hline & frogs & $82,6 \pm 2,34$ & $6,9 \pm 0,93$ & $7,0 \pm 1,12$ & $2,8 \pm 0,46$ & $0,4 \pm 0,24$ \\
\hline & rats & $45,4 \pm 1,89$ & $28,4 \pm 1,50$ & $23,0 \pm 1,34$ & $2,6 \pm 0,51$ & $0,6 \pm 0,24$ \\
\hline \multirow{3}{*}{$\begin{array}{l}\text { 2. Water from a } \\
\text { water supply } \\
\text { system }\end{array}$} & fish & $68,4 \pm 1,96^{*}$ & $12,6 \pm 1,24^{*}$ & $9,8 \pm 2,25^{*}$ & $2,4 \pm 0,42$ & $6,8 \pm 0,63^{*}$ \\
\hline & frogs & $65,1 \pm 0,96^{*}$ & $14,2 \pm 1,43^{*}$ & $11,2 \pm 1,82^{*}$ & $2,2 \pm 1,02$ & $7,3 \pm 0,44^{*}$ \\
\hline & rats & $35,4 \pm 1,63^{*}$ & $23,4 \pm 1,54^{*}$ & $37,6 \pm 1,91^{*}$ & $3,2 \pm 0,86$ & $0,4 \pm 0,24$ \\
\hline \multirow{3}{*}{$\begin{array}{l}\text { 3. Water from } \\
\text { the pump } \\
\text { room } \\
\text { (park named } \\
\text { Shevchenko) }\end{array}$} & fish & $86,2 \pm 2,46$ & $6,4 \pm 1,12$ & $5,2 \pm 0,67$ & $1,6 \pm 0,74$ & $0,6 \pm 0,69$ \\
\hline & frogs & $84,5 \pm 2,12$ & $6,6 \pm 0,67$ & $6,4 \pm 1,08$ & $2,2 \pm 0,37$ & $0,2 \pm 0,14$ \\
\hline & rats & $44,5 \pm 3,03$ & $27,0 \pm 1,67$ & $26,0 \pm 3,74$ & $2,3 \pm 0,48$ & $0,2 \pm 0,45$ \\
\hline \multirow{3}{*}{$\begin{array}{l}\text { 4. Packaged } \\
\text { water } \\
\text { "Heavenly } \\
\text { Krinitsa" }\end{array}$} & fish & $64,8 \pm 2,66^{*}$ & $14,9 \pm 2,25^{*}$ & $8,8 \pm 2,14$ & $4,4 \pm 0,91 *$ & $7,1 \pm 0,72 *$ \\
\hline & frogs & $64,7 \pm 2,62 *$ & $12,6 \pm 1,22 *$ & $13, \pm 1,04^{*}$ & $3,6 \pm 1,02$ & $5,9 \pm 0,12 *$ \\
\hline & rats & $34,8 \pm 2,82^{*}$ & $24,4 \pm 4,39 *$ & $32,4 \pm 2,25^{*}$ & $3,0 \pm 0,63$ & $5,4 \pm 0,68^{*}$ \\
\hline
\end{tabular}

Note: $*-\mathrm{p}<0.05$ compared with the control group; 
In the experiment using frogs, similar data were obtained. An increase in the number of monocytes $(14.2 \%)$, segmented neutrophils (11.2\%), eosinophils $(6.8 \%)$ and a decrease in lymphocytes $(65.1 \%)$ in tap water samples, almost the same data were obtained in the study of packaged water. Water from the pump room did not cause a cytotoxic effect.

White blood cells play an important role in protecting the body from toxic effects, bacterial and fungal infections. The occurrence of lymphopenia (a decrease in the number of lymphocytes) is characteristic of the initial stage of the toxic infectious process and is associated with their migration from blood vessels to tissues to foci of inflammation. According to the data (Vergolyas M.R., 2016) the effect of toxicants on the body is accompanied by changes in the quantitative composition of blood cells.

The data obtained in the experiment with rats indicate that the rats' leukocyte count of peripheral blood cells after drinking water for 6 weeks was also characterized by changes (Table 1). In the experimental group of rats that drank water from the water supply, an increase in the number of segmented neutrophils $(37.6 \%)$ was found along with a decrease in the number of lymphocytes $(35.4 \%)$ and monocytes $(23.4 \%)$. These data may indicate the development of an inflammatory reaction in the body of experimental animals. The data obtained in rats who consumed water from the pump room were close to control.

Violation of the ratio of cell populations of blood in animals that were given water "Heavenly Krinitsa" were significant compared with the control group. A decrease in lymphocytes (by $10.6 \%$ ) and monocytes (by $4.0 \%$ ), an increase in the relative number of segmented neutrophils by $10.4 \%$ and eosinophils by $4.8 \%$ were detected. The detected changes in the cellular composition of the peripheral blood of experimental rats may indicate the activation of nonspecific natural resistance, the development of inflammatory and allergic reactions (Table 1).
When determining the quality of drinking water using biotesting methods, a number of important questions arise regarding the extrapolation of the obtained results to the human body, such as, for example, whether toxicity data from water samples obtained using animal and plant test organisms are a danger signal for humans. According to the literature, the most suitable methods for extrapolating to the human body are methods that evaluate mutagenicity, gene and cytotoxicity, i.e. (sub) cellular effects. This conclusion is based on the results of several international programs (Gene-Tox, International Program on Chemical Safety IPCS), implemented in the 90s. Even changes in the cellular structures of plants, in particular onions, Allium cepa, suggest genotoxic and mutagenic effects for higher animals, including humans (Trachtenberg I.M., Kovalenko V.M., Kokshareva N.V., Zhminko P.G., Chumak V.T., Baula O.P., 2008; Goncharuk V.V., Vergolyas M.R. \& Boltina I.V., 2013).

More than 100,000 chemicals (EINECS) are registered in the European Register. Of these, the presence and concentration of only 30-40 chemicals are regularly checked in the most important ecosystems of European countries (Trachtenberg I.M., Kovalenko V.M., Kokshareva N.V., Zhminko P.G., Chumak V.T. \& Baula O.P., 2008; Antomonov M.Yu., 2006). A significant part of the substances cannot be determined in natural and waste waters due to the lack of appropriate analytical methods or the high cost of such analysis. Structural and quantitative changes in cells and nuclei are observed even at low concentrations of toxicants according to SanPiN 2.1.4.1175-02 (Sanitary rules and norms).

Our results of testing the cytotoxicity of drinking water at test sites, which include organisms with different levels of organization (fish, frogs and rats) allow us to draw the following conclusions.

\section{Conclusions and Prospects.}

Biomonitoring of natural and drinking water is an urgent task at the present stage of 
development of society, which is carried out by scientific teams in many countries of the world. Chemical analyzes in determining the quality of drinking water are not entirely justified, since chemical methods cannot reveal the entire set of elements present in an aqueous solution, evaluate their interaction and transformation in the environment and the body. Biotesting using optimal sets of test organisms and their cellular parameters objectively characterizes the biological component of water quality.

2. In the peripheral blood of animals under normal physiological conditions of the body, the formation of shaped elements is in equilibrium. Violation of the relationship between these processes, due to the reaction of the organism to irritation of toxic substances present in water and mani- fests itself in a change in the quantitative composition of peripheral blood cells.

3. Toxicity assessment using hematological parameters of test organisms of fish, frogs and rats complies with modern requirements for studies of the quality of water samples, allows to determine their biological activity at the cellular level. Recorded changes in blood parameters in the body objectively characterize the long-term effects of negative effects.

4. The data obtained indicate the promise of using hematological parameters of fish, frogs and rats in the biotesting of drinking water. The proposed method can be considered relatively humane in that the manufacture of peripheral blood preparations does not require the slaughter of experimental animals.

\section{References}

1. Trakhtenberh I.M., Kovalenko V.M., Kokshareva N.V., Zhminko P.H., Chumak V.T., Baula O.P. (2008). Alternatyvni metody i test-systemy [Alternative Methods and Test Systems]. Avitsena, 272.

2. Goncharuk V.V., Vergolyas M.R., Boltina I.V. (2013). Investigation of drinking water mutagenicity and genotoxicity. Journal of Water Chemistry and Technology. (35), 426-435.

3. Tytsa N.U. (2003). Klynycheskoe rukovodstvo po laboratornym testam [Clinical Guide to Laboratory Tests]. UNIMED-PRESS, - 942.

4. Vergolyas M. (2019). Assessment of drinking water quality at the cellular level. Adv Tissue Eng Regen Med Open Access. (5), 53-55.

5. Vergolyas M.R. (2016). Blood as integrated system of organism. ScienceRise. (2), 7-11.

6. V.V. Goncharuk, M.R. Vergolyas. (2013). State standard of Ukraine DSTU 7387:2013. Yakist vody. Metod vyznachennia tsyto- ta henotoksychnosti vody i vodnykh rozchyniv na klitynakh krovi prisnovodnoi ryby Danio rerio (Brachydanio rerio Hamilton-Buchanan). - Vved. 11.06.13. 22.

7. M.R. Vergolyas, V.V. Goncharuk. (2016). Toxic effects of heavy metals on the hydrobionts' organism. Journal of Education, Health and Sport. (6), 436-444.

8. Balakhovskyi Y.S. (1982) Rukovodstvo po klynycheskoi laboratornoi dyahnostyke [Guidelines for Clinical Laboratory Diagnostics]. Medytsyna, 235.

9. Antomonov M.Yu. (2006). Matematycheskaia obrabotka i analyz medyko-byolohycheskykh danny$\mathrm{kh}$ [Mathematical processing and analysis of biomedical data]. FMD, 558.

\section{АНОТАЦІЯ}

М. Р. Верголяс. Аналіз безпеки питної води на тест-організмах. Біоресурси і природокористування. 2019. 11, №3-4. C.32-38. https://doi.org/ 10.31548/bio2019.03.004

Анотачія. Забезпечення населення якісною питною водою є важливим завданням збереження здоров'я людини. У світовій практииі при очіниі якості води, крім хімічного аналізу проводять сумарну токсикологічну оиінку води, засновану на застосуванні різних методів біотесту- вання. Оиінка якості питних вод методами біотестування в останні десятиліття набула особливої актуальності у зв'язку зі стрімким зростанням кількості потениійно небезпечних хімічних сполук, шо забруднюють природні джерела питного водопостачання. Метою дослід- 
ження було оиінка токсичності питної води з різних джерел водопостачання (водопровідна, артезіанська, фасована) з використанням гематологічних показників тест-організмів: риби Danio rerio, шпориеві жаби Xепориs $i$ щури Wistar. Виявлено шо за хімічним складом водопровідна і фасована вода не відповідали вимогам ДСанПіН 2.2.4-171-10 (Державна санітарно-гігієнічна норма). Вода з-під крана мала перевишення вмісту $\mathrm{Fe}$ (в 6,3 раза), а фасована вода «Небесна криниия» перевишувала Si ma Mn (відповідно у 1,5 i 1,2 раза). За аналізу периферичної крові у піддослідних тварин иі води проявили иитотоксичний ефект - збільшення кількості моноиитів, нейтрофілів $i$ еозинофілів $i$ зменшення лімфочитів. Виявлені зміни в клі- тинному складі периферичної крові піддослідних тварин можуть вказувати на активачію неспечифічної природної резистентності, розвиток запальної та алергічної реакиї. Показники периферичної крові у тест-організмів, які вживали воду з бювету, були близъкі до контролю. Отримані дані свідчать про перспективність використання гематологічних показників тест-організмів риб, жаб і шурів в біотестування питної води. Запропонований метод можна вважати відносно гуманним в тому, що виготовлення препаратів периферичноїкрові не вимагає забою піддослідних тварин.

Ключові слова: питна вода, біотестування, тест-організми, иитотоксичність, лейкоцитарна формула крові

\section{АННОТАЦИЯ}

М. P. Верголяс. Анализ безопасности питъевой воды на Тест-организмах. Биоресурсы и природопользование. 2019. 11, №3-4. C.32-38. https://doi.org/10.31548/bio2019.03.004

Аннотаиия. Обеспечение населения качественной питьевой водой является важной задачей сохранения здоровъя человека. В мировой практике при оченке качества воды, кроме химического анализа, проводят суммарную токсикологическую оченку воды, основанную на применении различных методов биотестирования. Оченка качества питьевых вод методами биотестирования в последние десятилетия приобрела особую актуальность в связи со стремительным ростом количества потенииально опасных химических соединений, загрязняюощх природные источники питъевого водоснабжения. Целью исследования была оченка токсичности питьевой водъ из различных источников водоснабжения (водопроводная, артезианская, фасованная) с использованием гематологических показателей тест-организмов: рыбы Danio rerio, шпориевые лягушки Хепорие и крысы Wistar. Выявлено, что по химическому составу водопроводная и фасованная вода не отвечали требованиям ДСанПіН 2.2.4-17110 (Государственная санитарно-гигиеническая норма). Вода из-под крана имела превышение содержания Fе (в 6,3 раза), а фасованная вода «Небесна криниия» превышала Si и Mn (соответственно в 1,5 и 1,2 раза). По анализу периферической крови у подопьтных животных эти воды проявили иитотоксический эффект - увеличение количества моночитов, нейтрофилов и эозинофилов и уменвшение лимфочитов. Выляленнье изменения в клеточном составе периферической крови подопьтных животных могут указывать на активаиию неспеиифической естественной резистентности, развитие воспалительной и аллергической реакиии. Показатели периферической крови в тест-организмах, которъе употребляли воду из бювета, были близки к контролю. Полученные данные свидетельствуют о перспективности использования гематологических показателей тест-организмов рыб, лягушек и крыс в биотестировании питьевой воды. Предложенный метод можно считать относительно гуманнъм, поскольку изготовление препаратов периферической крови не требует забоя подопытных животных.

Ключевые слова: питьевая вода, биотестирования, тест-организмы, иитотоксичность, лейкочитарнал формула крови

Отримано 05.08.2019p. 